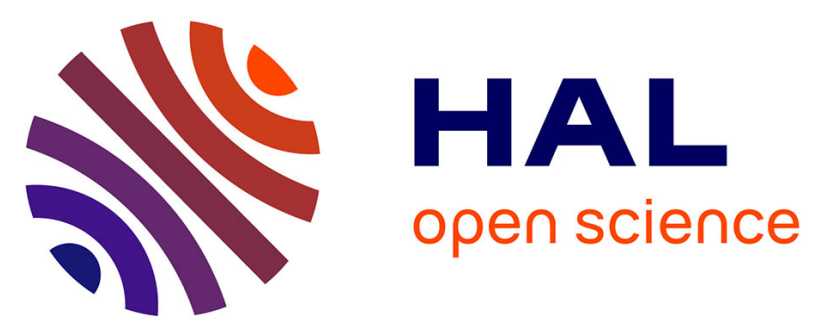

\title{
The Policy of Electro-Amplified Popular Music in France: the Liberal Context and the Regulation of Rebellious Cultures
}

\author{
Jean-Marie Seca
}

\section{- To cite this version:}

Jean-Marie Seca. The Policy of Electro-Amplified Popular Music in France: the Liberal Context and the Regulation of Rebellious Cultures. Mathieu Dehem (éd). Music and Law, Sociology of Crime, Law and Deviance, Volume 18, Emerald/The JAI Press, pp.103-127, 2013, 1521-6136. 10.1108/S15216136(2013)0000018008 . halshs-02967317

\section{HAL Id: halshs-02967317 \\ https://shs.hal.science/halshs-02967317}

Submitted on 14 Oct 2020

HAL is a multi-disciplinary open access archive for the deposit and dissemination of scientific research documents, whether they are published or not. The documents may come from teaching and research institutions in France or abroad, or from public or private research centers.
L'archive ouverte pluridisciplinaire HAL, est destinée au dépôt et à la diffusion de documents scientifiques de niveau recherche, publiés ou non, émanant des établissements d'enseignement et de recherche français ou étrangers, des laboratoires publics ou privés.

\section{(1)(1) $\$(0)$}

Distributed under a Creative Commons Attribution - NonCommercial - ShareAlikel 4.0 


\begin{abstract}
Purpose: The aim of this chapter is to theorize and describe the main characteristics of the social construction of the policy of electro-amplified popular music (EAPM) in the French context.

Design/methodology/approach: To explain the signification and the institutionalization of EAPM through the conflict and mediation between two modes of legitimation of the rebellion and recognition of identity: deliberative rationality and verbalization of protest, on the one hand, and "musicalization" of revolt and globalization of the rebellious feeling attitude, on the other hand.

Findings: The meaning of the so-called "musicalization of revolt" is defined. This phenomenon emerged, in France, at the end of 1960s, after a long and traditional period of "politization" and rationalization of protest. The main sociological and economic dimensions of this new historical process are designated: a special standardization of the emotional expression and a transcultural and global matrix of rebellion. Then, the public policy of EAPM is examined in depth. The paradox of the French voluntarism (the regulation of EAPM practices) is accentuated. What to do with the liberal origin of these styles and the institutional policy that began in 1982? Why and for what reasons has this public policy been still going on? What are the advantages of the public support from musicians' as well as local and national authorities' point of view? What are the topics of EAPM public policy (support for social creation, status of drugs, and ritualization of violence)?

Originality/value of power: This academic text offers some key concepts explaining the normalization of the emerging and anarchistic musical cultures.
\end{abstract}


Seca Jean-Marie, «The Policy of Electro-Amplified Popular Music in France: the Liberal Context and the Regulation of Rebellious Cultures », in Mathieu Dehem (éd), Music and Law, Sociology of Crime, Law and Deviance, Volume 18, Bingley,

\section{INTRODUCTION}

Over the past sixty years, in France, like in many other Western European countries, different social scientists and analysts have been witnessing a continuous, progressive global development of electroamplified popular music (EAPM), with its moments of statu nascendi and innovating explosions. This article examines the meaning of the relationship between popular rock/electric musical practices and law in a general sense. The "law area" of musical forms can be defined as an extended set of artistic and cultural practices that are marked, both content- and form-wise, by regulations, laws, occasionally committed analytical views held by social sciences scholars, and the effects of national, regional, or local public policies. These musical practices are considered to have received a judicial marking or a variable analytical and theoretical treatment, depending on the different contexts or styles. They have nonetheless undergone a scientific, economic, financial, social, professional, psychological, sociological, and creative minimal public regulation. For more than thirty years, they have been benefiting, depending on the time, from a certain orientation and psychological marker, although they emerged before the development of any specific laws, public actions, or decisions affecting their development or limiting their continuation. Social sciences specialists adopt, sometimes unawares, sometimes deliberately, this categorization as a susceptible element of treatment by a public policy.

After examining popular music from a socio-anthropological point of view, I will then focus on the context of the emergence and the main characteristics and causes of the public regulation of popular music in France. In order to provide a correct analysis of the dialectic between "popular music" and "public policies", I will employ the notion of "electro-amplified popular music", referring to a large set of musical styles (rock, metal, rap, reggae, techno, punk, etc.) as well as to its field of study. My aim is to mark out a few questions addressing the links between these styles and their administrative regulations. I will thus explore a vast area of activities non-specifically restricted to judicial texts themselves. The set of musical practices and contents to which I refer in this article includes historical and sociological elements of EAPM, some key dates of the emergence of popular music public policies, certain decrees and laws, as well as reactions of the public sphere to the various effects of these extremely effervescent phenomena and their relation with addiction or censorship.

\section{THE INSTITUTIONALIZATION OF EAPM AND THE "MUSICALIZATION" OF REVOLT}

Music is obviously the most accessible and the most ancient phenomenon of intercultural sharing. From a certain point of view, music, as a cultural form, is the best anticipation of our present. Jacque Attali rightly proposed to analyze the evolution of music production as an exploration of Utopia and of the new socio-economic modes (Attali, 1977). As such, music is the primitive conception of communication, networking, global thinking, and the divination of the future of society.

\section{Electro-amplified popular music: an anthropological definition}

The term "popular music" is, in this article, associated with the qualifiers "amateur" and "electroamplified", indicating creative, potentially protesting and entertainment tendencies and, at the same time, an electric, technological labeling ${ }^{1}$ (Frith, 1981; Chapple \& Garofalo, 1977; Hebdige, 1979; 
Seca Jean-Marie, «The Policy of Electro-Amplified Popular Music in France: the Liberal Context and the Regulation of Rebellious Cultures », in Mathieu Dehem (éd), Music and Law, Sociology of Crime, Law and Deviance, Volume 18, Bingley,

Middleton, 1990; Shuker, 1998; Street, 1986). This expression (EAPM) is used to highlight the double specificity of these trends in France: they are influenced by both Anglo-American matrices (the term "popular music" is very specifically defined in Cultural Studies: Shuker, op. cit.) and technological innovations/artistic creativity in the field of electricity (Touché, 2007, 1998, 1994).

Below are some characteristics of EAPM:

1. Communitarian styles and behaviors characterized by conspicuous symbols of marginality.

2. Ambivalent connections with conventions and with most music standards. This structural ambivalence is frequently transformed both into a need for dissidence and a need for stardom. The latter is accompanied by denial of identification with stars and leaders.

3. A position of refusal (characterized by rage and denial) or, conversely, an attitude of overinvestment toward marketing rationality models.

4. Defense (apologia for) and promotion of the popular character of its modes of diffusion/distribution/consumption.

5. A desire to have an audience at all costs ("need for recognition"), even if the public is limited to some friends or a small group of music producers.

6. An ambiguous will to preserve an expressive authenticity and originality.

7. Emergence and renewal of styles (rock, rap, metal, punk, techno) and modes of creation having their origins in technological inventions both in production instruments and sound diffusion (from electrical guitars to compact discs, from the miniaturization of the means of production to the complete digitalization of the processes of commercial production/distribution);

8. An aesthetic and intellectualized dissent (see the different protest songs as well as the punk attitude all over the world) against the mass cultures that have been reduced to strictly entertainment conformism.

9. Numerical hybridization and integration of world folklore and popular styles into a global pop market configuration (Portuguese electro-fado, Spanish and Gipsy flamenco, Latin-American salsa, Cuban nova trova, Algerian raï, African-urban styles, etc);

10. Anthropological phenomena of differentiation and normalization/integration of minority expression into postmodern societies.

11. Social representations (socio-cognitive and ritual systems that have become art doctrine) of music and arts in the amateur and little-known (or amateur, or garage) bands.

12. Increasing propagation of neo-pagan religions and experiences that is associated with the emergence of ever more musical trends and bands (Maffesoli, 1988, 2012).

Ever since the end of the Second World War, there has been an increasing global dissemination and standardization of different EAPM trends (from be-bop jazz to rock'n-roll, rap, reggae, soul and punk). They illustrate the typical process of creating social differentiation, entertainment, and pleasure (Buxton, 1985). This global process relates to an ideological (social representations) and commercial model of 
Seca Jean-Marie, «The Policy of Electro-Amplified Popular Music in France: the Liberal Context and the Regulation of Rebellious Cultures », in Mathieu Dehem (éd), Music and Law, Sociology of Crime, Law and Deviance, Volume 18, Bingley, Emerald/The JAI Press, pp. 103-127

innovation and uniqueness. It generates an aesthetic and emotional reflexivity that generally expresses an urban everyday life rejection, anxiety, or criticism as well as an alternative/utopian/ecological social life project. Some of these critical and political representations have been propagated through this effective and global model of business, aesthetics, and socialization.

\section{"Musicalization" of revolt versus "politicization-verbalization" of dissent}

I propose the expression "musicalization of revolt", which is probably connected with an innovative, original artistic protest process, which emerged toward the end of the First World War (Marcus, 1989). This movement is mainly opposed to that of "verbalization/politicization/militarization of dissent". The latter developed, in Europe and in The United States, from the beginning of the $19^{\text {th }}$ century to 1945 and flourished during the 1950s and the 1960s, more particularly with the hybrid style of the protest song. "Verbalization/politicization of revolt" is an ambiguous term because it includes not only "military and war" action in which most Western nations were involved, but also the rise of the study of everyday life as an academic field (Enlightenment philosophy movement, human rights actions, and also the criticism of consumption worlds). This ambiguity corresponds in fact to that of modernity: from its onset, the fight for Enlightenment and democracy became, for both the American and French Revolutions, nationalistic, practical, and warmongering.

The EAPM styles (rock and roll, rap, techno, metal, world music) appeared during the World and Cold Wars (1910-1960), a time of inversion/transformation of these rationalistic and nationalistic values. They were -and they are- exemplary crystallizations of another expression of crowd behavior. This "musicalization" illustrates the end of a certain type of coordinated protesting organization, also centered on fundamentalist, Marxist, and communist beliefs. At the same time, it materializes a global entertainment model and a current, dominant love and emotional group-feeling culture (or ordo amoris process: see Scheler, 1973):

"Social movements, and subcultures, especially those associated with youth, were seen in a much more positive light, at best as positive stages in social development mapping out nonestablished routes to adulthood, at worst as the unfortunate extremes of youthful idealism and alienation" (Eyerman, 2002, p. 444.)

As it is widely known, the claim for flower power in the 1960s was not solely a poetic attitude. It also symbolized the transformation of both majority norms and minority groups in terms of mobilization. Furthermore, the "musicalization" process has structural, political, and sociological characteristics. The use of an enlightening metaphor of the evolution of the erotic of the masses may illustrate this process. Hardly anyone ever dreams of having a notorious politician as lover or parent. However, this is how a wonder-struck nun, working as a warder in a psychiatric hospital, consoles the young Ida Dalser, Mussolini's tearful ex-lover: "Be happy that you've met this man and made you pregnant". Ida, whose life was turned into a film entitled Vincere by Marco Bellocchio, had sold everything to finance Benito Mussolini's propaganda newspaper, II Popolo d'Italia ${ }^{2}$, only to be rejected and ignored by him afterwards. She would fight in an asylum for the rest of her life to claim her role as Mussolini's wife and mother of their son, Benito Albino Mussolini. In the 1930s important political leaders were considered ideal men. Mussolini had hundreds of lovers (Olla, 2011). Adolf Hitler, despite his unattractive 
Seca Jean-Marie, «The Policy of Electro-Amplified Popular Music in France: the Liberal Context and the Regulation of Rebellious Cultures », in Mathieu Dehem (éd), Music and Law, Sociology of Crime, Law and Deviance, Volume 18, Bingley, Emerald/The JAI Press, pp. 103-127

appearance, would arouse the boundless admiration of German women (Leutheusser, 2001; Schaake, 2012). Ever since, the star-system has caused political leaders to gradually and inevitably go out of fashion. The Knight of the Sad Figure embodied by Silvio Berlusconi in Italy or Dominique StraussKhan's libertine behavior in France can only breed commiseration, contempt, or mockery in today's society. They become totally hermetic due to the reversal of values triggered in the Occident by the worship of heroes that are more evanescent, seducing, and close to the masses (reality-shows). So the need for submission remains. These values are now projected around entertainment, aesthetics, and music. However, this does not prevent ultraliberal or insidious totalitarianisms (pernicious programming of cultural contents) from spreading across Europe and beyond. This also explains why the present article argues in favor of an anthropological, musical, and aesthetic meaning of revolt/conformism (Godelier, 2009). In other words, the "musicalization" of revolt is the blank, projective, and virtual space of various institutional, political, and social needs. In this lengthy and strange movement, that includes a new ordo amoris, the "traditional" societies of Africa, South America, or North-Asia rejoin the dominant and rationalist Western countries.

\section{A standardization of feeling emotions despite local cultural and stylistic heterogeneity}

For the musical message to be "heard", it is necessary that a social knowledge of the environment as well as a manner of feeling emotions become of prime importance. It is futile to attempt to analyze the integrality of the stakes of the "standardization of feelings" as it is too lengthy a process and outside the scope of this paper (For further reference see: Seca, 2005, 2006, 2009). The standardization of feelings and of some corporal attitudes (erotic habits, fashion, and narcissist behavior) is part of this specific global ideology of EAPM. It complements the cultural heterogeneity in the local productions and the consecutive specific internalizations of theses styles. The confrontation between the global electroamplified rhythmic predominance of these styles and the local diversity of their reception explains why there is a continuation and even a stronger propagation of violent and enraged new creations. It is as if the conflicting impact of the standardization of feelings generates various "replications" and partial transformations of the previous reproductions, as in the case of the retrovirus in biology. Consequently, the controversial (standardization/heterogeneity) impact of these different styles seems to be in latent contradiction with their intercultural benefits and financial profit.

But in reality, there is no contradiction between the contribution of these expressive and stylistic modes, which are socio-economically reproduced, and their paradoxical and terse innervation of the social element because the expression of anger is frequently associated with rock, pop, rap, techno, hard-core, and metal. These styles are specifically the formalization of these tensions, contradictions, and various latent conflicts in all societies. In other terms, there is no real inconsistency between these different phenomena (differentiation / "replications" / standardization / communication / global development / conflict generated during the reception of an innovation). They are all elements of the same process: need for social recognition of the personal uniqueness in a collective reference. The expression of rage in musical underground styles and local contexts is naturally connected with the modulation and adjustment of communication, as well as with this need for differentiation and imitation (Seca, 2012). There are numerous examples from various countries where the pattern of this kind of protesting attitude both in aesthetics and EAPM has different consequences in terms of expression of 
Seca Jean-Marie, «The Policy of Electro-Amplified Popular Music in France: the Liberal Context and the Regulation of Rebellious Cultures », in Mathieu Dehem (éd), Music and Law, Sociology of Crime, Law and Deviance, Volume 18, Bingley,

feelings, emotions, anger, and repression (Seca, 2007). Additionally, in various western countries and globalized spaces, one notices nowadays the emergence and diffusion of six stylistic forms implying a technical deepening and an emotional intensification of aesthetic explorations of EAPM experiences (Lebrun, 2009; Seca, 2007). Here are the aforementioned stylistic forms:

- populist and identity rocks, among others.

- free parties (techno) practices.

- hard-rock and metal trends.

- reggae and soul/funk roots and hip hop/rap movements.

- punk revivals and hardcore styles.

- global world and specific folk music revivals.

Several questions can be addressed at this stage. Despite the nuances of regional and local appropriation described above, can one talk about the advent of a trans-cultural matrix of rebellion? Is this matrix ever a source of change and transformation? This seems highly unlikely. If there is a standardization process, founded by these musical forms, is this tendency in relation to an accentuation of individuation (to be singular in small similar groups) and psychopathological regression? Or is it the opposite, that is to say this process encourages, crystallizes, and materializes an ever more important dissemination of minorities' behaviors and patterns of real creativity? This second interpretation seems far more plausible. Furthermore, the "musicalization" of revolt is strongly associated with the influence of a specific model of "internality" (very often studied in social psychology: Beauvois, 1994; Dubois, 1994). The increase of the internalized causal attributions in different cultural and organizational fields (and in musical practices) means that this trend goes hand in hand with:

1. A general psychiatrization / psychologization of social relations.

2. An excessive obsession with individual/standardized/marketing/influenced bodily cultures.

3. An ideology of charismatic, gifted personality.

4. A worship of the body and modified states of consciousness.

5. A narcissistic "instrumentalization" of otherness.

There is a symbolic meta-system (social representations) which organizes the influence of EAPM productions and their latent impact: it is more effective than traditional propaganda because it is centered on the after-effect of minority as private influence (Channouf, 2004; Moscovici, 1976; Moscovici \& Mugny, 1987; Nemeth, 1987). This global ideology of minorities and of individuals spreads naturally and emotionally in the reserved daily life of the people and is a mirror of a global dissent. It is no surprise if some philosophies, such as "situationism" or Nietzschean thinking, have become more meaningful and illustrative of the apologia for EAPM trends and "minority attitude" (Debord, 1967; Marcus, op. cit.). As mentioned above, there are ever more Dionysian or pagan rituals as well as aesthetic emotions (Mombelet, 2009; François, 2006; Walzer, 2007). They consist of acts, symbols, and crystallizations of this matrix. They are structured as a system of socially shared assertions about rebellion, community, body, pleasure, future, and self-conception in the world.

This symbolic and representational matrix of EAPM also includes a puritan and religious refusal/promotion of idolatry (Seca, 1991). It shows a permanent and structural rebellion against institutions and law (Martin, 1979). Simultaneously, there are colossal networks of fans, multinationals, 
Seca Jean-Marie, «The Policy of Electro-Amplified Popular Music in France: the Liberal Context and the Regulation of Rebellious Cultures », in Mathieu Dehem (éd), Music and Law, Sociology of Crime, Law and Deviance, Volume 18, Bingley, Emerald/The JAI Press, pp. 103-127

official leadership, stardom, etc (see the internationalized funeral of Michael Jackson in 2009; for more on fan cultures see: Ferrand, 2010; Le Bart, 2000). This explains why this specific culture, qualified as "utopia" by its organic supporters or intellectuals, or as commercial ideology by its critics, is greatly influential (Adorno, 2001, 1989; Bloom, 1987; Finkielkraut, 1987; Seca, 2010). In the eyes of conservatives and academics, these "cultures" are defined as "an ideology" and a source of "addiction attitudes". Within this academic trend, EAPM is a symptom of the relative decline of the "logos" and Kantian deliberative philosophy (Dufour, 2007; Stiegler, 2008), holding the advantage of an essentialist, narcissist, and communitarian conception (a claiming/protesting democracy value; for more on this view, see: Taylor, 1989).

Conversely, an idealization of "neo-tribalism" is emerging among producers, supporters, poets, and musicians: in a large number of video clips featuring a style or a group, recurrent images of crews, tribes, posses, and gangs are put on the screen. This apologia for the basic and tribal group supporting a musical style has been dealt with at length in English Cultural Studies or by some French sociologists (Maffesoli, 1988, 2012). This group idealization implies a prevalence of fetishism (accentuation of the image of a specific style) and a "fluidic" representation of musical action, that is an increasing promotion of the hypnotic efficiency of art and of what Maisonneuve calls the "corporization"I "bodyism3" (a general body interactive feeling ideology: cf. Seca, 2001; Maisonneuve, 1976). Another constructive characteristic of the matrix of EAPM is a specific design of creativity: self-training, technological and instrumental minimalism, individuation career with functional use of the group, despite the formal promotion of collective benefits. This use of DIY pertains to a cultural position that is extremely hybrid, at times incoherent and at best « innovating », supported by a solidarity/brotherhood philosophy and a libertarian-individualistic inspiration. Depending on the point of view, it can be liberal, neo-tribal, resourceful, emergent, adaptable, or, on the contrary, progressive, radical, rebellious, disjunctive, antifamilist, autonomous, loyal, utopist, alternative (Bey, 1997; Deleuze \& Guattari, 1972; Hein, op. cit.; Guibert, 2006).

\section{THE MAIN CHARACTERISTICS OF THE FRENCH PUBLIC POLICY OF EAPM}

Ever since the 1980s the French public policies of these electro-amplified styles have constituted, in a way, a rare national experience of long-term (modest, but constant) voluntary funding of production and dissemination of protesting cultures, in Europe and in the world. As a preamble to the explanation that follows, it is important to stress that these musical styles, more than other cultural forms, represent, due to their mode of emergence and dissemination, a minority and liberal culture whose origin can be placed between the cinema, the dream, and the mythical North American territories whose frontiers first reached London. This profound and ancient impact of North American cultures upon Europe and France is not a sensational discovery, but it is essential to point it out. For example, we note a wellknown and old tradition of the "French touch" in Jazz music (for example Stefan Grappelli, Django Reinhardt, and more recently Michel Pietrucciani). Like in many European countries (for example Lonnie Donegan in Great Britain: Price, 2010), rock and jazz music began to be listened to in the very early 1950s, for example with artists using an English surname in the Latin countries (Touché, op. cit.). 
Seca Jean-Marie, «The Policy of Electro-Amplified Popular Music in France: the Liberal Context and the Regulation of Rebellious Cultures », in Mathieu Dehem (éd), Music and Law, Sociology of Crime, Law and Deviance, Volume 18, Bingley, Emerald/The JAI Press, pp. 103-127

One also notices an increasing popularity of rock music protests in France (1979-1988): identification of many young people with the punk model and English new wave, during the stage of my first investigations: 1979-1987 (Seca, 1988). Since 1982-1983, there have been numerous and various appropriations of American hip hop in the French suburbs (Marseille, Lyon, Paris, etc), giving birth to a mixed and relatively original French rap. Still in the 1980s, the concept of "world music" began to be diffused in Paris by Nova Radio, for example (an audio broadcast of the underground music periodical Actuel). From 1995 onwards, a multiplication of other trends has emerged (mainly techno, straightedge, cyberpunk, and metal). Recently, some revivals of punk and a commercial standardization of French rap could be observed. Like in other Western countries (the United Kingdom, the United States, Scandinavia, Italy, or Germany), all these trends are strongly structured and organized. They have networks, periodicals, websites, and radios. These networks consist of active consumers and small groups of producers and artists, who are present both in cities and villages, with their own associations, their lobbying activities, and the intention to influence the decisions of the Parliament, the government, or the regional and local authorities.

\section{The « cause of musicians » following the "Cause du Peuple"}

After the Cause du Peuple 4 , a French Maoist newspaper, forerunner of Libération, and sold by JeanPaul Sartre in the 1960s, « the cause of musicians » has gradually and metaphorically emerged. It has often been used as an « object of strategic transaction » since the 1970s, including by the unions of disc producers (Kaiser, 2012; Zafiropoulos \& Pinell, 1982). This tendency towards the instrumentalization of artistic activities greatly exceeds the concerns and specific interests of aesthetes and artists themselves, be they "guerrilleros of style or protest", "skilled entrepreneurs of easy-listening songs", or "creators of genius". A perfect illustration of this would be the ethnography of the "2000 Parking" lot (Seca, 1988, 2001). At the beginning of the 1980s, there was a quarrel over a Parisian underground parking lot which had been abandoned by motorists and turned by punk, West Indian, reggae, or hardrock amateurs into a place for rehearsal and musical creation. As a result, a battle of image and « points of view » between the Ministry of Culture (of socialist orientation with Jack Lang at its head) and the City Hall of Paris (governed by Jean Tibéri, a Gaullist conservative close to Jacques Chirac) took place in the press ${ }^{5}$. The amateur groups of this parking lot had tried to take advantage of this rivalry, albeit without success for they were gradually expelled around 1986-1989. This symbolic battle projected around the legitimacy of rock practices taking place in a sordid underground parking lot is indicative of the utter destitution existing in the rehearsal and concert premises of the then EAPM producers. This conflict stereotypically broke out between the two parties either to glorify or justify the disparaging of marginal experiences as well as a certain type of youth "in the name of security" or "against drug trafficking". This type of "dispute", which received a lot of media coverage, is also indicative of the context in which certain leftist politicians or cultural advisers deliberately chose to support EAPM at the time.

Consequently, the public policy of EAPM began in 1982 in correlation with the access to power of socialist movements (1981-1986; 1988-1992; 1997-2002). A significant moment was the creation of "La Fête de la musique6" in 1982 by the Left Party Minister Jack Lang, former founder of the Theatre World Festival in Nancy, an event that has enjoyed tremendous success ever since. After its accession to 
Seca Jean-Marie, «The Policy of Electro-Amplified Popular Music in France: the Liberal Context and the Regulation of Rebellious Cultures », in Mathieu Dehem (éd), Music and Law, Sociology of Crime, Law and Deviance, Volume 18, Bingley,

power, the left-winged government put at the centre of its philosophical policy the notion of creation as a general and quasi-anthropological objective of cultural policies (Decree of 10 May 1982), which defined the mission of Jack Lang, the then Minister of Culture, as follows:

"Allow all French people to cultivate their capacity for invention and creation, to express their talents freely and to receive the artistic training of their own choice; to preserve the national, regional, or social heritage to the benefit of the entire community".

One of the aims was to "attain cultural democracy" with EAPM becoming an emblematic practice, continuing the endeavor of the popular history of the Maisons des Jeunes et de la Culture ${ }^{7}$ (a network of cultural democratization initiated during the Front Populaire in the 1930s and after the Second World War, in 1944) and the spirit project of the preceding governments round the idea of "cultural development" (André Malraux). 22 July 1982 marked the founding of the Youth Interministerial Committee. Starting 1982, ministerial notes aimed at "encouraging youth cultural practices (focus on neighborhoods, promotion of cultural activities in educational settings, spare time and vacations)" (Teillet, 2003, p. 160).

More broadly, various experts called for the development of a logic concerning the projects to be implemented as well as for the need to multiply a diversity of places of cultural investment by young people. EAPM had a privileged role in this quest to adjust to the needs of the so-called "young groups" (at the instigation of the following ministerial advisers: J.-M. Lucas, J. Hurstel, and B. Lion). As an example, the cultural militant Bruno Lion became in 1989 "project adviser for rock music" for Jack Lang. He would promote a dynamic of voluntary action in the field of EAPM (creation of a network of small and large concert halls, federations of musical actors, devices of professionalization, opening of rehearsal and creation centers).

As a result, the conservative, liberal, or social governments that followed would continue the general philosophy initiated in 1982 by Jack Lang's nebulous advisers and those for cultural and creative development. The continued existence of funding devices and envelopes would then be ensured (especially to help the foundation of local and regional scenes or to guarantee minimum professionalism in these sectors). An example of the continuation of this policy is a statement that Jean-Jacques Aillagon, Minister of Culture and Communication in the conservative government of Jean-Pierre Raffarin, made in 2002 speaking of EAPM:

"I intend to give them a place in accordance with their pre-eminence in the cultural practices of young generations. The government's commitment to reduce VAT rate on discs is above all a policy for young audiences and musicians, who produce and consume most of these discs. Besides, the Ministry of Culture and Communication will continue to support local collectivities concerning the implementation of musiques actuelles halls, rehearsal studios, festivals and will favor the progressive opening of music schools [...]. More than often [...], the towns want to offer young people music venues. I believe that we have to support their projects by also proposing training and vocational programs for the musicians who wish to attend such courses ${ }^{8}$. 
Seca Jean-Marie, «The Policy of Electro-Amplified Popular Music in France: the Liberal Context and the Regulation of Rebellious Cultures », in Mathieu Dehem (éd), Music and Law, Sociology of Crime, Law and Deviance, Volume 18, Bingley, Emerald/The JAI Press, pp. 103-127

The political framework for EAPM was thus set out and has been continued to this day with its low but also strong moments, such as the concerted action supporting the performing arts by the Ministry of Culture of Catherine Trautmann, between 1998 and 2002.

\section{The emergence of a sector of EAPM social and solidarity economy}

A priori, it is difficult to understand this type of public policy in favor of EAPM, because, from an American standpoint, it addresses trends that remain singular, emergent, elusive, free, diversified, anomic, deviant, and innovating, thus dependent on a culture permeated by the market or anarchic spirit. It is important to remember that these extremely effervescent and evanescent creative and artistic forms are indicative of a Darwinian vision of minorities who "should become successful through their own commercial outlets and the satisfaction of the public", which is sometimes promoted (rightly or wrongly) in more liberal contexts, such as the United States. All these remarks help to render the political aspect of EAPM funding ever since 1982 in stark contrast to the marketing matrix of promoted practices. This originality and mismatch characterize a real cultural French specificity in this field (Dauncey \& Le Guern, 2010; Le Guern, 2007; Le Guern \& Dauncey, 2007). It is certainly not a paradox that emerging cultural activities should be regulated. On the contrary, it is a standard feature of numerous cultural policies, particularly the propagandistic ones. Nevertheless, it is rare that protest cultures should be continuously supported publicly and nationally (ever since 1981). It is an extraordinary idea to publicly fund the most various projects pertaining to groups whose objectives are often anomic, inconstant, mischievous, marked by free market principles and symbolizing, at the same time, a spirit of protest as much as the lightest form of entertainment. Doesn't this kind of policy of public support lead to a new orthopraxis and conventionalism of "chosen" cultures by certain (semi) public actors (associations) and consequently to neo-conformist and "funded EAPM"?

A sociological and philosophical characterization of this type of state intervention accounts for a French specificity: regulation of dissemination, support for production, protection of emergent experiences, dialog with social minorities, recuperation of atomized rebellions by an open participation on the local scene. The origin of this attitude of public support (at a state, regional, or local-communal level) can be identified in a number of ideological discourses defending counter-cultures (IRMA, FEDUROK or UFISC: http://www.ufisc.org/presentation-de-l-ufisc/manifeste-statuts.html). These discourses stem from a political and philosophical glorification of the public and corporatist preservation/appropriation of countercultures. They are inspired or influenced, at least in France, by a radical ideology emerging in the 1960s in the United States and Europe, as described in the first part of this chapter (situationism, DIY ideology, activism, libertarian leftist ideology, influence of Bourdieu's sociological ideas, and a popular education drawing upon a wide range of sources, be they Christian, personalist, communist or libertarian). This public policy of current musical practices has led to:

a. A reasoned and comprehensive assessment of opposing minds.

b. A will to help to pre-professionalize activity sectors seen as socio-economically, technically, and aesthetically marginal, but potentially useful to cultural production systems (see IRMA: a national EAPM association financed by the Minister of Culture and Communication: http://www.irma.asso.fr/). 
Seca Jean-Marie, «The Policy of Electro-Amplified Popular Music in France: the Liberal Context and the Regulation of Rebellious Cultures », in Mathieu Dehem (éd), Music and Law, Sociology of Crime, Law and Deviance, Volume 18, Bingley, Emerald/The JAI Press, pp. 103-127

c. A desire to culturally counter, transform, and even sublimate the deviances and anomy of deprived urban neighborhoods (Lafargue de Grangeneuve, 2008).

This institutionalization and professionalization process of EAPM leads to the development of the socalled "Third Sector". The term is an excellent example of how the intercultural practice is developing in a specific area, in this case within the French social welfare system. From the point of view of cultural activism and of the French amateur and professional EAPM associations, the term "Third Sector" is connected with the revolutionary and connotative concept of "Tiers État" (Third State) that concentrated, in 1789, all the representatives of the People in the Parliament. Metaphorically speaking, "Third Sector", also reflects an alternative economic and social solidarity of some enterprises and non-profit associations ${ }^{9}$. What's more, "Third Sector" indicates all kinds of alternatives to industries and services controlled by strictly stock exchange and financial logics. Various national associations (TECHNOPOL, FEDUROK, IRMA, etc.), different kinds of networks of concert halls, several independent productions, numerous conferences and festivals of musicians and producers (FORUMA, Transmusicales of Rennes, Festival of Bourges, Rock en Seine- in Paris), many professional training courses, as well as technical and commercial help activities confirm the existence of a strong institutionalization of amateur and EAPM policy.

Ever since the 1980s, there have been innovative trends in the public regulation of popular music in terms of social and solidarity economy. This blurry but politically and discursively active sector of activity is developing alongside the market economy of music production (associations, groups, musicians' federations, professionalization structures, multiplicity of festivals supported, to a great extent, by public funding). The state or regional / local support for the production / dissemination of popular music (rap, techno, world music, rock, metal, jazz, etc) has been also part of an irrigation strategy of fluid and renewed networks of artists and groups. This also led to investments in a wide network of concert halls covering the entire French territory through the policy promoting halls of musiques actuelles: the SMAC operation 10 represents about half of the national subsidies granted to EAPM. The possibility of performing in these locally and nationally funded concert halls comes to be a new criterion for the recognition of emergent groups. This was completed by the implementation of a radio quota of francophone songs (in 2000) and a data protection law combating digital piracy (Law HADOPI 2009-669 of 12 June 2009 promoting online diffusion and protection of musical creation).

One observes, in this public policy of EAPM, a functionalist and utilitarian relation with the law and the state and administrative institution, whether it concerns the management of digital copyright (the combat of the conservative government of François Fillon between 2007 and 2012) or the support for production / diffusion venues. In such a judicial and administrative context, French counter-cultural musical styles are strangely free, conformist, at once savage and domesticated, autonomous and dependent on subsidies obtained through a complex system of associations funded indirectly by local or national authorities. At the same time, we have been witnessing, ever since the 1990s, a stylistic diversification of trends related to rock, pop, and rap, as if the strongest dissemination of "authentic cultures" were accompanied by a stronger sophistication of auditor musical expertise and subsequently by an exacting and informed segmentation of taste. Previously dissident styles, such as rock, end up acquiring an "academic status" and to a certain degree a canonical status; additionally, other cultures come into being through counter-differentiation (Lescop, 2012; Coulangeon, 2010). 
Seca Jean-Marie, «The Policy of Electro-Amplified Popular Music in France: the Liberal Context and the Regulation of Rebellious Cultures », in Mathieu Dehem (éd), Music and Law, Sociology of Crime, Law and Deviance, Volume 18, Bingley, Emerald/The JAI Press, pp. 103-127

A concerted, administrative process between actors aiming at enforcing the professionalism of these musical practices was superimposed on the public regulation and segmentation of cultural taste. Disc industries, organizers of festivals, tours, and concerts agreed to create a commercial, administrative, and vaguely socializing appellation (in French "musiques actuelles") so as to neutralize the stylistic, reductionist, and political connotations related to rock and rap. The term "musiques actuelles" has become a strategy to better communicate with the Legislator and public decision makers as well as to classify a wide range of styles.

'The term 'musiques actuelles' has been preferred, from the beginning of the 1980's, following its usage by the actors themselves. Indeed, it seems that M. Lidou, who participated in the creation of Transmusicales of Rennes and the Center for Information and Resources of Musiques actuelles, used it when addressing political leaders so as not to refer to the political and sound dimensions that other designations suggested, even though the actors in question seem to have preferred the terms of 'rock' and 'pop'. Musiques actuelles still means to the (French) political leaders all non-elitist musical forms, from jazz to rock, including chansons, variétés, rap and techno styles, but also 'traditional' music, which is even more problematic. Hence the existence of the National Center for chanson, variétés, and jazz (CNV), regional centers for musiques actuelles" (Kaiser, 2012, pp. 191-192.)

The collective and bureaucratic creation of this special expression ("musiques actuelles" in French) to designate this kind of music indicates how the specialization of the State Administration in this field of music policy is developing. It is another indicator of the official handling of EAPM. Studies on music and amateur practices have abounded from 1973 onwards, especially after 1982 (DEP of the French Ministry of Culture11: http://www.culture.gouv.fr/dep/). At the same time, one can observe a continuous non-evaluation and non-control of cultural expenditures by many local authorities, with consequences such as a prevalence of favoritism / nepotism or ideological choices in financing decisions (see chapter Le Guern \& Dauncey, 2007). This situation is a potential source of conflict. One can also spot an increasingly institutionalization and a certain disorder in some locally activated public policies. Obviously, it is not easy to control the satisfaction of the proliferating Dionysian need in rock practices and other types of electro-amplified music. The main demand of rock and rap bands, ever since the origins of these movements (especially in American "garage bands", for example), has been to be treated equally ("we can do it too"). The characteristics of this public policy in local urban spaces are in direct contradiction with the aim of punk or rock revolt. As mentioned above, EAPM was born in anomic and deregulated contexts. French policy is inspired by a regulatory (rationalistic? humanistic?) philosophy of culture and social control. This paradox explains and justifies the diffusion of an often plaintive and "underground/rebellious" mini technocracy claiming subsidies and requiring even more attention. This can lead to unequal support of some styles, at the expense of others. In other words, the French regulation model of music bands will potentially help to legitimate certain artists rather than others, more or less wild or conformist. This contradiction does not hinder a parallel maintenance of a hierarchical representation of cultural values (between elitist and classical music and EAPM, for example). One observes a typical and stereotypical direction of the public resources when it comes to culture: a small amount of the money goes to amateur EAPM bands, whereas ever more financial support is provided for jazz, opera, avant-garde, experimental or classical music ${ }^{12}$. 
Seca Jean-Marie, «The Policy of Electro-Amplified Popular Music in France: the Liberal Context and the Regulation of Rebellious Cultures », in Mathieu Dehem (éd), Music and Law, Sociology of Crime, Law and Deviance, Volume 18, Bingley,

Last but not least, this kind of policy ("Third Sector", local and national subsidies, maintained hierarchies of arts, and a continued preference for some kinds of EAPM bands or trends) as well as that of the market (small companies linked with great labels and desire for success) lead to a chaotic but also tonic development of these musical trends in France.

\section{About other interference between legislation and EAPM}

It is impossible to review here all of the phenomena lying at the intersection between EAPM and its politico-judicial regulation. As already mentioned, certain consecutive sociological effects of this integration / regulation (for example a sort of vulgarization / dissemination / segmentation of rock, rap, techno, and metal experience), whether judicial or administrative, can be explained by the virulence of a pro-active and pro-youth EAPM philosophy continuing since 1982. It has led to a normalization I integration / recognition of aesthetics of contestation and to the attribution of an academic status to this rebellious / commercial / emergent music. The consequence was a sort of "underground orthopraxis" opposed to the non-programmed draft modes of creation and production reigning in these circles. This underlying and inexorable "legitimation of a traveling entertainer" and this enchanted valorization of youth cultures often take place so as to recognize, on the one hand, the most diversified aptitudes of the new generations, and on the other hand, cultural innovation. The change that this large process of institutionalization of rebellious cultures has inscribed in the semantics of these musical styles is the result of years of concerted public action. It implies immeasurable psycho-sociological and political consequences on the management of social rage and its aesthetic dissemination. One of these effects is the annexation of revolt and intellectual opposition to the field of admissible cultural programming.

The question of the status of addiction and drugs in general also marks legislative and pro-active interventions, for example in the field of techno-festive events ("free parties"). The application in France of the 2002 Mariani decree on the obligation to declare to the Police Commissioner any festive events bringing together more than 250 people has decreased the number of free parties and altered their form ever since the first seizures of equipment made by law enforcement agents. A large number of "nonscheduled" techno events have been closely monitored for various reasons (whether from an ethnological or administrative point of view or police related: Epstein \& Fontaine, 2005; Pourtau, 2006, 2005). One notes in particular that, after the Mariani decree on controlling drug trafficking in techno musical events, illegal sales have been transferred to other venues, less marked by psychedelia. The strategy employed by offenders has been to roam the nightclubs and other festive venues marked by other stylistic trends. The relation with substance abuse is regularly evoked as a pretext for the control of a lot of festive events and their risks. In France, these types of behavior are not a private affair.

The reasoning may be the same for everything related to sectarian practices, closely monitored by the Central Bureau of Worship (BCC) of the Minister of the Interior and by the MIVILUDE (the Interministerial Mission of Vigilance and Fight against Sectarian Abuses), dependent on the Prime Minister. This latter institution is based on an individualistic, rationalistic, and universalistic philosophy of the French republic where any occult group or movement, or having a mysterious influence on individuality, is regarded as potentially dangerous. The individual is defined in the French Constitution as the only legal entity of republican conceptualization of citizenship, in the name of the principle of secularism 
Seca Jean-Marie, «The Policy of Electro-Amplified Popular Music in France: the Liberal Context and the Regulation of Rebellious Cultures », in Mathieu Dehem (éd), Music and Law, Sociology of Crime, Law and Deviance, Volume 18, Bingley, Emerald/The JAI Press, pp. 103-127

separating religion and political life. In this context, a sect or any collective entity may be, if its hold becomes too strong, declared harmful to the individual's mental equilibrium. According to the MILIVUDE, a sect leads to:

"the perversion of the freedom of thought, of opinion, or of religion violating public order, laws and regulations, fundamental rights, security, and individual integrity. It is characterized by the implementation by an organized group or an isolated individual, irrespective of its nature or activity, of pressure or techniques with a view to create, maintain, or exploit the individual's state of psychological or physical subjection, partially depriving him / her of his / her free will, with damaging consequences on that individual, his / her circle, or society at large" (see: http://www.miviludes.gouv.fr/).

As an example, this inter-ministerial group examined at length the satanical activities of metal bands in France and their harmful effects on youth (MIVILUDES, Report 2007, 3 $3^{\text {rd }}$ April 2008). Shortly after the publication of this report, militant sociologists protested, rightly13 arguing that a large number of these amateur metal musicians did not take themselves seriously by worshipping Satan in their concerts (Bobineau \& al., 2008) or adolescent pranks, despite 92 cases of satanical profanations identified by the authors of the report of the MIVILUDES between January 2007 and November 2007.

Then, there is a whole range of battles of unemployed artists and regulating interventions in the employment of artistic workers that include musical practices and pertain to the relationship between law and music. Job management is thus a subject classically associated with "culture" as an economic driving force by left-winged parties. This type of discourse is regularly heard and read in audiovisual and written media. The French sociologist Pierre-Michel Menger (of the EHESS-Paris) studied the entertainment industry in great detail, noting the artists' capacity for survival by managing on their own and using more favorable unemployment benefits (Menger, 2002, 2011). With regard to EAPM, half of the musicians studied in the doctoral research of Gérôme Guibert were professionalized by using the unemployment benefits for artists and entertainment workers (Guibert, op. cit.).

Finally, the relation with the law is significantly present in France (as well as in the US) in the judicial monitoring of certain lyrics and clips of musicians trying to either defend their royalties or promote a radical cause through provocation or transgression by being sexually vulgar or by chiefly attacking the police or the French nation. In the US there were parental protests against "explicit lyrics" and certain trends considered very provoking (Benetollo, 1999). The French Ministry of the Interior prosecuted mainly rap bands (including various and more or less popular and financially successful groups such as Ministère Amer, Suprême NTM, Abdul X, Morsay and his gangsters, Sniper, etc). In France, as in the US, the attitudes of certain musicians in battles of the bands border on gangsterism. One notable event is an exchange of videoclips posted on Youtube between La Fouine (a rapper from Yvelines department, close to Paris) and Bouba (from the department of Hauts-de-Seine, still in the Paris area). These two artists challenged each other for the most unpredictable reasons through insults and provoking rap. The latest episode culminated in a pistol shot fired at La Fouine's car close to his home. Publicity stunt? Real violence? Overstatement? The judicial inquiry will answer these questions. The chronicle of anathema against the French state or police authorities is too long to be listed. It implies 
Seca Jean-Marie, «The Policy of Electro-Amplified Popular Music in France: the Liberal Context and the Regulation of Rebellious Cultures », in Mathieu Dehem (éd), Music and Law, Sociology of Crime, Law and Deviance, Volume 18, Bingley, Emerald/The JAI Press, pp. 103-127

dreaded issues related to law but also counter-counter-cultural reactions (for example the Gabber movement which claims an antirap and ultranationalistic position).

\section{CONCLUSION}

As a conclusion, this article examined EAPM as an appropriated and interiorized socio-cultural phenomenon in the French economic and political sphere while addressing a number of topics related to legislation and public regulation. There are many other examples. We did not tackle the complex legislation ${ }^{14}$ with regard to the French language radio quota. These laws have nowadays some influence on the aesthetic and linguistic strategy of many French EAPM emergent bands, such as the language (English or French) used in theirs shows. The implementation of cultural policies is not a strictly French prerogative to act. It is nonetheless rare to read the history of a country so accurately when it comes to cultural public policies. It is well known that songs are indicators of current events and form a useful system of indicators for the study of the mentalities of a culture. As such, the image of EAPM in France reflects at once the influence of cultural globalization strongly influenced by musical movements of Anglo-American origin - but also African and West Indian - as well as a long political history of revolts and dissidences typical of this country. The impact of 1968 and everything related to it in terms of emotions and memories (anger, rage, transformations of sensitivities, ideological after-effect of American cultural radicalism, fashion movement, feminism, passage from combative leftism to rock and other musical forms of activism, emergence of an alternative punk scene towards the end of the 1970 's) also play a primordial role in France, enabling us to understand why so many people wanted to bring to the forefront sounds and words, creative and representational aptitudes, which were attributed to cultural minorities and despised by the elites and dominant groups of the 1970's and 1980's. This instrumental and romantic combat fitted perfectly within a long revolutionary history which is excellently illustrated in the novels of Victor Hugo and Emile Zola and which is part of the emotional fiber of a large part of popular categories whether they are politically oriented or not. However, it is important to note that even the French far right tried to favor an "identity rock", following the example of the English National Front which attempted to instrumentalize the skinheads of the 1980s (Lescop, 2007). Philosophical and intellectual battles aiming to define the nature of emergent cultural situations are as such neither innocent nor neutral when it comes to the consequences of their sociological, judicial, administrative, and political categorization, whether in the medium or long term.

\footnotetext{
${ }^{1}$ See International Association for the Study of Popular Music (http://www.iaspm.net/).

2 Like some groupies that sacrificed themselves for an idolized music band.

3 In French the neologism is "Corporéisme".

4 In English: "The Cause of the People".

5 The Minister of Culture descended to the fourth basement of this parking lot, in 1985, for strategic and political motivations:

"Jack Lang fait une descente dans le 4e sous-sol du rock", Libération, 25 avril 1985.

6 Translation: "The Music Day"

7 Trad.: Cultural and Youths Centers.

${ }^{8}$ In Trax. Magazine des musiques électroniques, n56, October 2002, p.62.

${ }^{9}$ This entrepreneurial, social, and social sciences research movement led to the creation in 2012, under the French socialist government, of the position of Minister of Social and Solidarity Economy and Consumption.

10 SMAC: Scène de Musiques Actuelles (operation officially initiated by a Ministerial Circular of 18 August 1998 after about ten years of "café-musique", "festivals", and "Zenith network" support). The SMAC mission promotes both the diffusion of
} 
Seca Jean-Marie, «The Policy of Electro-Amplified Popular Music in France: the Liberal Context and the Regulation of Rebellious Cultures », in Mathieu Dehem (éd), Music and Law, Sociology of Crime, Law and Deviance, Volume 18, Bingley,

Jazz and EAPM, accompanying practices including rehearsal, training, creation, and cultural action. The SMAC network consisted of 150 locations in 2011, out of which about 70 were nationally subsidized (about 9 million euros were granted by the French Ministry of Culture). Supplementary SMAC subsidies come from local authorities (more than $55 \%$ of its public support).

${ }^{11}$ Despite this increasing institutionalization, the academic recognition of the social scientists specialized in the study of musical studies is not at the same level and legitimacy as what they are in British and American universities (see Dauncey \& Le Guern, 2010).

12 Other and larger subsidies are invested for more legitimized musical activities in "National Scene" (50 million euros), "National Centre of Musical Creation" (3 million euros), "Opera Houses" (more than 26 million euros), and "Classical and operatic Orchestra" (more than 22 million euros).

${ }^{13}$ Raphaël Liogier, "Révolution culturelle dans la lutte antisectes", Le Monde, 3rd March 2008.

14 These laws of 1986 and 1994 were modified on August, 1, 2000.

\section{REFERENCES}

Adorno, T. (2001). Le Caractère fétiche dans la musique et la régression de l'écoute, trad. fr. Paris: Allia (1 ${ }^{\text {st }} \mathrm{Ed}$. in German language: 1973).

Adorno, T. (1989). Théorie esthétique, trad. fr. Paris : Klincksieck (1'st Ed. in German language: 1970).

Attali, J. (1977). Bruits. Essai sur l'économie politique de la musique. Paris: PUF.

Beauvois, J.-L. (1994). Traité de servitude libérale. Analyse de la soumission. Paris: Dunod.

Bey, A. (1997). The Temporary Autonomous Zone. Ontological Anarchy, Poetic Terrorism: Anarchy and Conspiracy. London: Forgotten Books.

Benetollo, A. (1999). Rock et politique. Censure, opposition, integration. Paris: L'Harmattan.

Bloom, A. (1987). The Closing of American Mind. New York: Simon \& Schuster

Bobineau, O, Bisson, D., Mombelet, A. \& Walzer, N. (2008). Le Satanisme. Quel danger pour la société ? Paris: Pygmalion.

Buxton, D. (1985). Le rock, star système et société de consommation. Grenoble : La Pensée Sauvage.

Channouf, A. (2004). Les Influences inconscientes. De l'effet des émotions et des croyances sur le jugement. Paris: Armand Colin.

Chapple, S. \& Garofalo R. (1977). Rock'n'roll is here to pay: the history and politics of the music industry. Chicago: Nelson Hall.

Coulangeon, P. (2010). Sociologie des pratiques culturelles. Paris : La Découverte.

Dauncey, H. \& Le Guern P. (2010). Stereo: Comparative Perspectives on the Sociological Study of Popular Music in France and Britain. Farnham/Burlington: Ashgate Publishing Limited.

Debord, G. (1967). La société du spectacle. Paris: Gallimard.

Deleuze, G. \& Guattari, F. (1972). L'Anti-CEdipe. Capitalisme et schizophrénie. Paris: Minuit.

Dubois, N. (1994). La Norme d'internalité et le libéralisme. Grenoble: PUG.

Dufour, D.-R. (2007). Le Divin Marché. La révolution culturelle libérale. Paris: Denoël.

Dutilh, A. \& Varrod D. (Ed). (1998). Rapport de la Commission nationale de musiques actuelles à Catherine Trautman, Ministre de la Culture et de la Communication. Paris: Ministère de la Culture et de la Communication. 
Seca Jean-Marie, «The Policy of Electro-Amplified Popular Music in France: the Liberal Context and the Regulation of Rebellious Cultures », in Mathieu Dehem (éd), Music and Law, Sociology of Crime, Law and Deviance, Volume 18, Bingley,

Epstein R. \& Fontaine A. (2005). De l'utilité des raves: consommation de psychotropes. Mouvements, $42,12-21$.

et action publique

Eyerman, R. (2002). Music in Movement: Cultural Politics and Old and New Social Movements. Qualitative Sociology, 25(3), 443-458.

Ferrand, L. (2010). La Vie en rock. Une approche compréhensive de la culture rock par ses acteurs : les amateurs, Ph. D., under the direction of Prof. M. Maffesoli. Paris: CEAQ/University of Paris-V.

François, S. (2006). La Musique europaïenne: ethnographie d'une subculture de droite. Paris: L'Harmattan.

Finkielkraut, A. (1987). La Défaite de la pensée. Paris: Gallimard.

Frith, S. (1981). Sound Effects. Youth, Leisure and the Politics of Rock'n roll. New York: Pantheon Book.

Godelier, M. (2009). Communautés, sociétés, cultures: trois clés pour comprendre les sociétés en conflit. Paris: CNRS

Guibert, G. (2006). La production de la culture. Le cas des musiques amplifiées en France. Genèse, structurations, industries, alternatives. Paris / Saint-Amand Tallende : Irma/Mélanie Séteun.

Hebdige, D. (1979). Subculture: the Meaning of Style. New York/London: Terence Hawkes.

Hein, F. (2012). Do It Yourself! Autodétermination et culture punk. Congé-sur-Orne: Le Passager Clandestin.

Kaiser, M. (2012). Les politiques publiques liées aux musiques populaires en France : la dimension culturelle en question, Ph.D under the direction of E. Prof. Maigret. Paris: University of Paris-III.

Lafargue de Grangeneuve, L. (2008). Politique du hip-hop: Action publique et cultures urbaines. Toulouse: Presses Univ. du Mirail.

Le Bart, C. (2000). Les Fans des Beatles. Sociologie d'une passion. Rennes: PUR.

Lebrun, B. (2009). Protest Music in France. Production, Identity and Audiences. Farnham \& Burlington: Ashgate Publisher.

Le Guern, P. (2007). En arrière la musique ! Sociologies des musiques populaires en France. La genèse d'un champ. Réseaux, 141, 15-45.

Le Guern, P. \& Dauncey, H. (2007). De la difficulté d'émerger sur les scènes de "musiques actuelles": les exemples de la France et de l'Angleterre. In J.-M. Seca (Ed). Musiques populaires underground et représentations du politique. Cortil-Wodon: InterCommunications / EME., 84112.

Lescop, G. (2012). Skinheads: du reggae au Rock Against Communism, d'une contre-culture à une "contre-contre-culture" sous influence musicale. Volume! Contre-Cultures, Théories \& Scènes, 9(1), 129-149.

Lescop, G. (2007). De la fascination musicale : stratégies et représentations de l'extrême droite. In J.-M. Seca (Ed.). Musiques populaires underground et représentations du politique. Cortil-Wodon: InterCommunications/EME, 244-271. 
Seca Jean-Marie, «The Policy of Electro-Amplified Popular Music in France: the Liberal Context and the Regulation of Rebellious Cultures », in Mathieu Dehem (éd), Music and Law, Sociology of Crime, Law and Deviance, Volume 18, Bingley,

Leutheusser, U. (Ed.). (2001). Hitler und die Frauen. München: W.H. Verlag.

Maffesoli, M. (1988). Le Temps des tribus. Le déclin de l'individualisme dans les sociétés de masse. Paris: Klincksieck.

Maffesoli, M. (2012). Homo eroticus. Des communions émotionnelles. Paris: CNRS.

Maisonneuve, J. (1976). Le corps et le corporéisme aujourd'hui. Revue française de sociologie, 17(4), $551-571$.

Marcus, G. (1989). Lipstick Traces: A Secret History of the Twentieth Century. Cambridge : Harvard University Press.

Martin, B. (1979). The Sacralization of Disorder: Symbolism in Rock Music. Sociological Analysis, 40(2), 87-124.

Menger, P.-M. (2011). Les intermittents du spectacle. Sociologie du travail flexible. Paris : EHESS ed.

Menger, P.-M. (2002). Portrait de l'artiste en travailleur. Métamorphoses du capitalisme. Paris : La République des Idées / Le Seuil.

Middleton, R. (1990). Studying Popular Music. Milton Keynes : Open University Press.

Mombelet, A., (2009). Le Metal. Un projet mythologique articulé au jeu et au don. Ph. D. under the direction of Prof. M. Maffesoli. Paris: CEAQ/University of Paris-V.

Moscovici, S. (1977). Social Influence and Social Change. London : Academic Press.

Moscovici, S. \& Mugny G. (Eds.). (1987). Psychologie de la Conversion. Études sur l'influence inconsciente. Fribourg: Delval.

Nemeth, C. J. (1987). Au-delà de la conversion: formes de pensée et prises de décision. In S. Moscovici \& G. Mugny (eds.). Psychologie de la conversion. Études sur l'influence inconsciente. Fribourg: Delval, 239-250.

Olla, R. (2011). II Duce and His Women: Mussolini's Rise to Power. London: Alma Books Ltd.

Pourtau, L. (2006). Consommation de substances psychoactives et transe fonctionnelle dans les fêtes techno. Psychotropes, 12 (3-4), 163-181.

Pourtau, L. (2005). Les interactions entre raves et législations censées les contrôler. Déviance et Société, 29(2), 127-139.

Price, J. (2010). Lonnie Donegan, Rock Island Line, et la corne d'abondance. Volume, 7(2), 115-140.

Schaake, E. (2012). Les Femmes et Hitler. Leur rôle dans l'ascension du Führer. Paris : R. Laffont (1'st German edition: 2000).

Scheler, M. (1973). Selected Philosophical Essays. Evanston: Northwestern University Press.

Scheler, M. (1933). Vorbilder und Führe. In Schriften aus dem Nachlass, Berlin (in Gesammelte Werke), Trad. In French: 1958, Le Saint, le Génie et le Héros, Lyon, Vitte Ed.

Seca, J.-M. (2012). Colères et ordo amoris dans les styles rock. Sociétés, 117(3), 15-33.

Seca, J.-M. (2010). Conduites minoritaires et représentations sociales. Saarbrücken: Éditions universitaires européennes. 
Seca Jean-Marie, «The Policy of Electro-Amplified Popular Music in France: the Liberal Context and the Regulation of Rebellious Cultures », in Mathieu Dehem (éd), Music and Law, Sociology of Crime, Law and Deviance, Volume 18, Bingley,

Seca, J.-M. (2009). Musiques extrêmes, déviance et violence: normalisations et conversions: entretien avec Julie Cerizay. Les Cahiers de psychologie politique, 15 (on-line Journal: URL: http://lodel.irevues.inist.fr/cahierspsychologiepolitique/index.php?id=832).

Seca, J.-M. (Ed) (2007). Musiques populaires underground et représentations du politique. CortilWodon: InterCommunications.

Seca, J.-M. (2006). Représentations et ritualisations de la violence : quelle position scientifique peut-on avoir face aux musiques "extrême" ? Les Cahiers de psychologie politique, 8 (on-line Journal: URL: http://lodel.irevues.inist.fr/cahierspsychologiepolitique/index.php?id=1068).

Seca, J.-M. (2005). Formatage du ressentir et représentations underground. Sociétés, 90(4), 57-69.

Seca, J.-M. (2001). Les Musiciens underground. Paris : PUF.

Seca, J.-M. (1991). Les purificateurs du rock. Les Cahiers internationaux de Sociologie, 90, 121-130.

Seca, J.-M. (1988). Vocations rock. L'état acide et l'esprit des minorités rock. Paris: MéridiensKlincksieck.

Shuker, R. (1998). Key Concepts in Popular Music. London: Routledge.

Stiegler, B. (2008). Prendre soin de la jeunesse et des générations. Paris: Flammarion.

Street, J. (1986). Rebel Rock - The Politics of Popular Music. New York: Basil Blackwell.

Taylor, C. (1989). Source of the Self: The Making of the Modern Identity. Cambridge: Harvard University Press.

Teillet, P. (2003). Publics et politiques des musiques actuelles. In O. Donnat \& P. Tolila (Eds). Le(s) public(s) de la culture. Paris : Presses de Sciences Po, 155-180.

Touché, M. (2007). Muséographier les "musiques électro-amplifiées". Pour une socio-histoire du sonore. Réseaux, 141, 97-141.

Touché, M. (1998). Mémoire vive. Premier tome de recherches menées avec l'association Musiques Amplifiées d'Annecy. Paris/Annecy: CNRS/Le Brise Glace.

Touché, M. (1994). Connaissance de l'environnement sonore urbain. L'exemple des lieux de répétition. Vaucresson : Rapport de recherche CRIV-CNRS.

Walzer, N. (2007). Les Imaginaires satanique et païen: le cas de la musique metal extrême: une volonté de puissance schizomorphe. Ph. D. under the direction of Prof. M. Maffesoli. Paris, University of Paris-V.

Zafiropoulos, M. \& Pinell, P. (1982). Drogue, déclassement et stratégies de déqualification. Actes de la recherche en sciences sociales, 42, 61-75. 